\title{
Mediasodasta mediasivistykseen
}

\author{
$\underline{w}$ \\ Sodat ja konfliktit ovat juurruttaneet uusia käytäntöjä median \\ toimintaan. Nämä käytännöt näkyvät myös keskustelussa \\ koulutuksesta. Vaihtoehtoisten puheenvuorojen ja näkemysten \\ kuuluminen edellyttää mediasivistystä.
}

SOTIEN JA KONFLIKTIEN keskellä käytävä mediasota on ilmiö, jonka vaikutukset ulottuvat myös yhteiskunnalliseen keskusteluun. Mediakamppailuissa omaksutut toimintamallit ja -tavat näkyvät toimittajien ja tiedottajien arjessa ja siten heijastuvat esimerkiksi keskusteluun koulutuksesta. Samalla yhteiskuntamme medioituminen on johtanut siihen, että median käyttö- ja lukutaidosta on tullut välttämätön kansalaistaito. Tämän päivän aikuinen ei pärjää ilman riittävää mediasivistystä.

Tiedonvälityksen nopeutumisella ja maailman pienentymisellä on viestinnän kannalta monenlaisia seurauksia. Maailma on täynnä faktoja ja informaatiota, joista tiedonvälityksen ammattilaisten kuuluu tunnistaa olennaiset, merkittävät ja merkitykselliset asiat, karsia ja tiivistää. Journalistit ymmärtävät maailmaa muiden puolesta, toimivat silminä ja korvina. Minkälaisia identifioitumiskohteita tiedotuskoneistot ja toimittajat tarjoilevat? Minkälaisia suhteita rakentuu toimijoiden - tiedottajien, toimittajien, haastateltavien ja yleisön - välille? (Fairchlough 1997, 14.)

Toimittajien ammatti-identiteetille riippumattomuus on korvaamatonta, mutta niin riippumattomuus kuin omat havainnotkin joutuvat usein koetukselle. Joskus toimittajat vetäytyvät toimituspolitiikan taakse torjuessaan aiheen julkaisun tai hylätessään juttuvinkin. Journalistin tekemät tulkinnat ja analyysit eivät ole koskaan puolueettomia, vaan ne edustavat aina jotain näkökulmaa. Tiedotuskoneistojen ja journalismin suhde on symbioottinen: ne ovat monella tavalla riippuvaisia toisistaan ja tukevat sekä vahvistavat toistensa auktoriteettia. (Luostarinen 1994, 45.) 


\section{MEDIA TUNKEUTUI OLOHUONEISIIMME}

Ensimmäinen television mahdollistama "olohuonesota" käytiin 1960-luvun puolivälissä Yhdysvaltojen sotkeutuessa Indokiinan sotaan. Yhdysvallat tuki Etelä-Vietnamia, kun taas Pohjois-Vietnamin joukot saivat tukea Kiinalta ja Neuvostoliitolta. Yhdysvaltain sotimista Vietnamissa seurasi yli neljäsataa akkreditoitua kirjeenvaihtajaa. Toisen maailmansodan aikana elokuvateattereissa näytettiin uutiskatsauksia taisteluista ja sodan etenemisestä, mutta Vietnamin sodan tapauksessa uutisoinnista tuli päivittäistä. (Hallin 1986, 129.)

Yhdysvallat pyrki tarjoamaan toimittajille paremmat toimintaedellytykset päästämällä heidät joukkoosastoihin ja tilannekuvauksiin sekä jakamalla tietoa. Tilannetiedotuksista saadun tiedon laadussa ei ollut kehumista, sillä taistelutappiot kuvattiin niissä vain "kevyiksi", "kohtuullisiksi" tai "raskaiksi". Sensuurin korvasi joukko akkreditoinnin ehtona toimivia ohjeita, jotka rajoittivat sotilasoperaatioiden tiedon julkaisua. (Hallin 2009, 280.) Toimittajat osoittautuivat isänmaallisiksi ja uskoivat Yhdysvaltojen torjuvan kommunismia ja auttavan vietnamilaisia. He hyväksyivät virallisen kannan Yhdysvaltain menestyksestä taisteluissa. Sodan pitkittyessä kansalaisten ja poliitikkojen muodostaman kotirintaman asenteet muuttuivat kuitenkin kielteisiksi sotaa kohtaan. Taisteluista, haavoittuneista ja kaatuneista otetut kuvat lisääntyivät merkittävästi. (Hallin 2009, 283.) Kontrasti amerikkalaisten sotilaiden ja vihollisen - hyvän ja pahan - välillä kävi televisiosodassa yhä epäselvemmäksi, ja poliittinen erimielisyys lisääntyi (Hallin 1986, 120).

Yleisesti nähtiin, että tiedotusvälineet olivat ratkaisevassa roolissa ja että uutisointi johti mielipiteiden ja politiikan muutokseen. Lähempi tarkastelu osoittaa, että näin ei ollut. Tiedotusvälineisiin vaikutti kolme tekijää, joista ensimmäinen oli eliitin mielipiteiden hajaannus. Journalistien lähteet olivat tuttuja poliitikkoja ja hallinnon virkamiehiä, ja kun hallinnon sisäiset yhteydet (ulko- ja puolustusministeriö, Valkoinen talo) katkesivat, tiedotusvälineiden rooli näytti kasvavan. Toinen merkittävä vaikutin oli yleinen mielipide, sillä mielipidekyselyt osoittivat yleisön suhtautuvan sotaan epäilevästi jo sodan alusta saakka.
Kolmantena merkittävänä tekijänä toimi yhdysvaltalaisten sotilaiden laskenut moraali Vietnamissa. (Hallin 2009, 284-287.)

Daniel C. Hallin kuvaa median toiminta-alueita Vietnamissa (kuvio 1). Oikeutettujen kiistojen alueella yhteiskunnassa käydään sallittua ja hyväksyttyä kamppailua esimerkiksi armeijan toiminnasta tai poliittisista erimielisyyksistä. Sen sisimmällä kehällä on konsensuksen alue, jossa toimittajat eivät kyseenalaista yhteiskuntaa, eivät esitä vastakkaisia näkemyksiä eivätkä ole puolueettomia tarkkailijoita. Toimittajan tehtäväksi jää edistää yhteiskunnan yksimielisyyttä. Piirin ulkopuolelle jää poikkeavuuden alue, jossa poliittiseen valtavirtaan kuulumattomat ja hylätyt näkemykset jäävät kuulumatta. (Hallin 1986, 116-117.)

Yhteiskunnan normaalioloissa ulkokehien rooli on suurempi, mutta kriisissä, konfliktissa tai sotatilassa konsensuksen vaatimus kasvaa, ja eripuraiset äänet ja mielipiteet pyritään vaientamaan tai syrjäyttämään.

\section{MAINOSTOIMISTOT VALTAAVAT MEDIASODAN}

Persianlahden ja Bosnian sodan tapaisissa konflikteissa viestintä- ja mainostoimistojen rooli kasvoi suureksi. Viestintätoimistojen välittämän sotakuvan vaikutuksen todenmukaisuutta on lähes mahdotonta arvioida. (Kempf 2002, 59.) Samalla kun PR-koneistojen rooli ja propagandan teho on muuttunut, journalistien työn rajoittaminen poolien, valvonnan ja viivyttämisen avulla on kasvanut. Erityisesti Yhdysvalloille on ollut tärkeää, että Vietnamin sodan tapaiset virheet eivät toistu sen sotilasoperaatioissa (Luostarinen 1991, 36-37). Sodat ja taistelut ovat ennennäkemättömän PR-koneiston julkisuushallinnan testausta, minkä lisäksi ne ovat tiedotusvälineissä saaneet videopelin luonteen. Televisio esimerkiksi toimii vastaanottimena tutkakuville ja ohjuksen päässä oleville kameroille. (Knightley 2000, 483; Luostarinen 1994, 119-120.)

Myyttien, fantasioiden, retoriikan, petoksen, vihollisuuksien luomisen ja virallisen manipuloinnin päällekkäisyys teki Irakin sodasta uudenlaisen propagandan näyttämön vuonna 2003. Sodassa vaimot seurasivat aviomiestensä sodankäyntiä suorana lähe- 


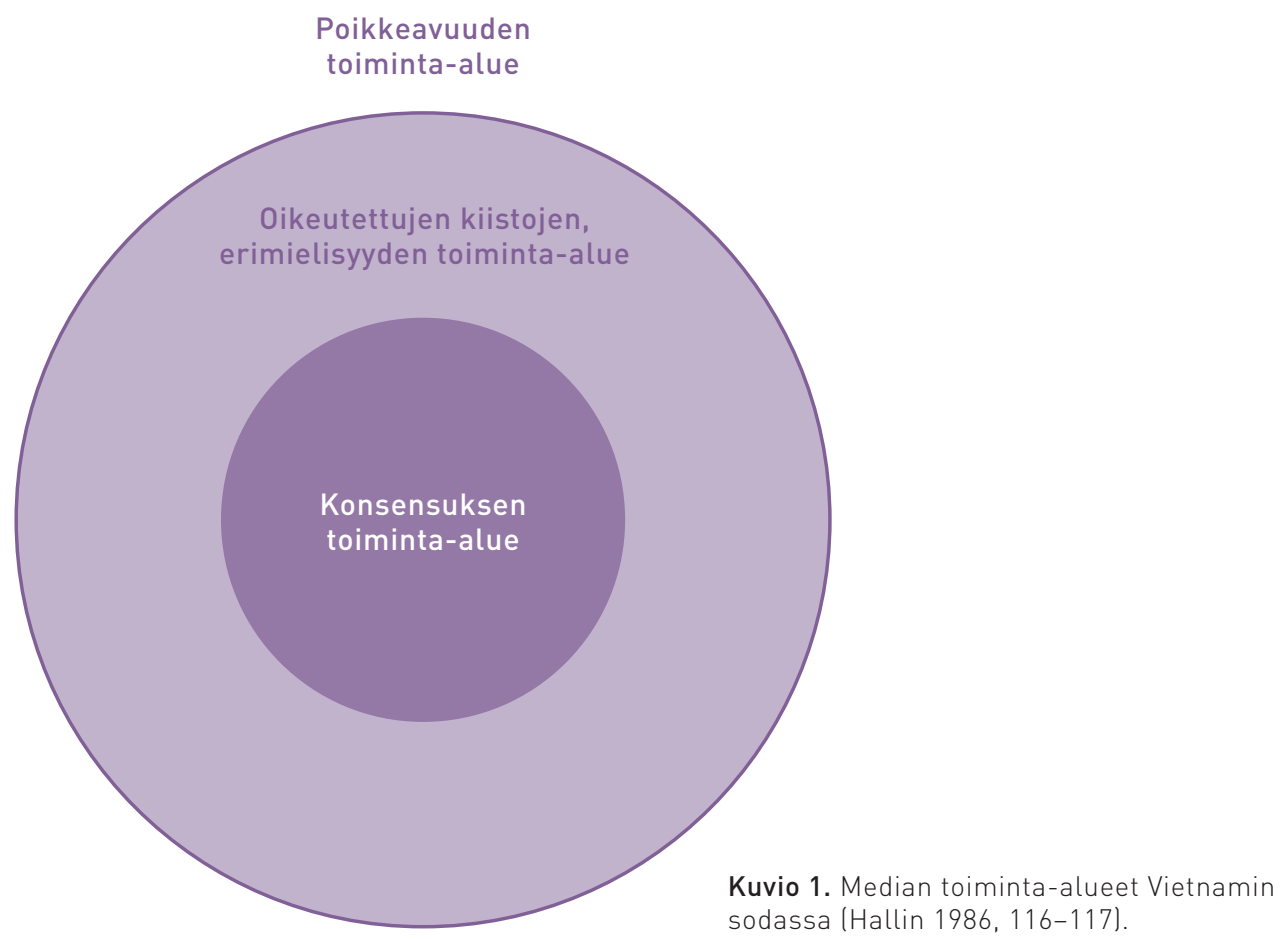

tyksenä eturintamalta (Jackson 2004, 212). Kun valitut toimittajat ja mediat päästettiin eturintamaan seuraamaan maataisteluiden etenemistä, he sisäistivät myös armeijan arvot ("when you wear the uniform, you buy the values"). Satelliittipuhelimien ja kameroiden kaltaisten teknisten välineiden käyttö loi uudenlaisen sodan, jossa synteesi muodostui satojen videokuvien koosteesta (kokonaisena seinämänä plasmanäyttöjä ja videotauluja) Qatarin komentokeskuksen tiedotustilaisuuksissa. Uutta teknologiaa esiteltiin niin aseiden kuin viestinnänkin muodossa. Esimerkiksi Qatarin Hollywood-vaikutteinen teatteri oli osa psykologista sodankäyntiä ja amerikkalaisen ylivoiman esittelyä arabimaiden paikallisille toimittajille. Sodan kaksi myyttiä olivat Saddam Husseinin ja Osama bin Ladenin liittolaisuus sekä Irakin joukkotuhoaseet. (Jackson 2004, 210, 213-214.) Kummastakaan ei löytynyt näyttöjä.

Median vastaanottaja voi kokea sodan television, radion ja internetin kautta reaaliaikaisena representaationa, joka vaikuttaa mediakuluttajiin uudella ta- valla. Mediasodassa konfliktin tai kriisin kokijana on laaja yleisö, jota sota aikaan ja paikkaan sidottuna ilmiönä ei enää kosketa. Sota on "tuolla jossain", mediassa, ei lähiympäristössä. Katsomme päivittäin sodan näyttämöä, palavia autoja, tuhottuja koteja, sekä kodittomia ja nöyryytettyjä ihmisiä, vaikka meillä ei näytä olevan mitään tekemistä varsinaisen sodan kanssa. Täsmäpommitukset huipputeknologisine aseineen vievät ajatukset pois ihmisten kärsimyksestä materian tuhoon tai tietokonepeleihin. Voimme halutessamme vaihtaa kanavaa viihdeohjelman kohdalle ja unohtaa koko sodankäynnin. (Huhtinen 2006, 103.)

Susan L. Carruthers muistuttaa median ja sodan symbioottisesta suhteesta: sotateollisuuden, vallassa olevan eliitin ja (amerikkalaisten) viestintävälineiden suhde on tiivis. Välillä vallankäyttäjät ovat pakottaneet myös paikallista mediaa sodan lietsontaan ja propagandan välitykseen, kuten kävi Serbiassa ja Ruandassa. (Carruthers 2000, 51.) Persianlahden sota ja presidentti Bushin "terrorisminvastainen sota" osoittavat, että mediaa ei aina tarvitse edes pakottaa. Paikallinen 
media on itsekin hyödyntänyt nationalismia uutisaiheiden, myynnin ja yleisön lisäämiseksi.

Yhdysvalloissa, IsossaBritanniassa ja Israelissa median suhdetta sodankäyntiin on tutkittu paljon. Mailla on riittänyt julkisuudenhallinnan testauskenttiä ja tutkittavaa sotilaallisissa konflikteissa (muun muassa Vietnamin, Grenadan, Libyan, Panaman, Falklandin saarten, Pohjois-Irlannin, Balkanin, Persianlahden, Afganistanin, Libanonin, Gazan ja Länsirannan konfliktit). Viimeaikaiset sodat ja konfliktit osoittavat mielipiteen muokkaamisen olevan voimissaan. Poliittisella eliitillä on edelleen tarve rakentaa sosiaalista todellisuutta konfliktin kulusta (esimerkiksi Irakin, Serbian ja Bosnian esimerkit) sekä vaikuttaa mediaesitysten sisältöön armeijan toteuttamalla median hallinnalla (military media management) ja PR-toiminnalla (Kempf 2002, 24).

Sodat ovat juurruttaneet uusia käytäntöjä median toimintaan. Mediasta on helppo havainnoida keskusteluteemoja ja juttuaiheita, joissa konsensus on käsin kosketeltavaa. Kotimaan uutisoinnissa tällaisia aiheita ovat tällä hetkellä esimerkiksi talous, turvallisuus, säästöt sekä vaatimukset palkanalennuksista ja talkoista. Oikeutettujen kiistojen ja erimielisyyksien alueelle pääsevät esimerkiksi koulutuksen säästöt. Keskusteltaessa koulutuksen sisällöistä päädytäänkin poikkeavuuden alueelle, jonne harva toimittaja haluaa mennä.

Koulutuskeskustelu on suomalaisessa mediassa lapsipuolen asemassa verrattuna esimerkiksi yhdysvaltalaiseen koulutuskeskusteluun, totesi professori Pasi Sahlberg tammikuussa Sitran seminaarissa Bostonissa. Professori on oikeassa. Koulutuskeskustelu vaatii toimittajilta ja medioilta asiantuntemusta, jota ei tämän päivän tiedotusvälineistä löydy. Koulutus on epäseksikäs aihe, aikuiskasvatuksesta puhumattakaan.

\section{IDENTITEETTIMME SYNTYY MEDIASSA}

Viestinnän tutkijalle identifioituminen on merkit- tävä tutkimuskohde, jonka kautta ymmärrämme ihmisten (media)käyttäytymistä. Identifioitumisella tarkoitan eläytymistä, samaistumista, myötätunnon ja sympatian tuntemista. Toisaalta vastaidentifioituminen merkitsee toiseuden, uhkan tai viholliskuvien kokemusta. Media tarjoaa identifioitumisen vaihtoehtoja ja identifikaatioita. Identifikaatio ilmaisee identiteettiä tarkemmin prosessin dynaamisuuden, monipuolisuuden ja vaihtuvuuden.

Selfie, Facebook- tai Twitter -päivitys, jaettu kuva, blogi tai perinteinen yleisönosastokirjoitus ovat osa jokapäiväistä mediakäyttäytymistä. Identiteetti on yksi yleisimpiä inhimillisiä tarpeita. Yksilöllä tai ryhmällä on tarve muodostaa itsestään käsitys muista erottuvana erillisenä kokonaisuutena. Identiteetistä käydään kamppailua: se on hauras ja epävarma, kestää tai pirstoutuu rajojensa turvallisuuden mukaan. (Bauman 1996, 161.) Identiteetit eivät diskursiivisesti ajateltuina ole itsestäänselvyyksiä, syntymän kautta saatuja leimoja tai muuttumattomia faktoja, vaan ne rakentuvat arkisessa kielenkäytössä, historiankirjoissa, tiedotteissa, median kuvissa ja sanoissa. Identiteettiä ilmaistaan ja kuvataan kielenkäytössä, ja samalla siitä neuvotellaan. Identiteetti on prosessi: ihmisessä kamppailevat tai neuvottelevat koko ajan monenlaiset identiteetit, ja eri tilanteissa - aina vuorovaikutuksesta laajempiin yhteiskunnallisiin tilanteisiin - risteilevät erilaiset identiteetin mahdollisuudet. (Pietikäinen ja Mäntynen 2009, 63-64.)

Ihmisellä on lukuisia tapoja määritellä itsensä. Pysyvimpiä ovat kansallinen, etninen (uskonto, rotu, sukupuoli) ja kulttuurinen identiteetti. Postmodernin tulkinnan mukaan ihmisessä on myös hybridinen eli tilanteellinen tai sisäkkäinen identiteetti. Ihmisen identiteetillä on monenlaisia ulottuvuuksia, jotka voivat tilanteiden mukaan saada erilaisen painoarvon ja merkityksen. Ammatti-identiteetti on yksi tällainen. Identiteetit voivat olla joskus ristiriidassa keskenään tai jopa yhteen sopimattomia, 
mikä johtaa identifikaatiomme jatkuvaan vaihteluun. (Hall 1999, 22-23.)

Yhteisöllisyys voi syntyä nopeasti ja intensiivisesti esimerkiksi koetun vääryyden, kansalaistoiminnan, viharyhmän tai solidaarisuuden ympärille. Tällainen verkostoidentiteetti ei synny tyhjästä, mutta ei välttämättä ole myöskään ensisijainen identiteetti, vaan muodostuu tavallisesti olemassa olevien identiteettien päälle tai rinnalle. (Linjakumpu 2009, 48.)

Susan Greenfield väittää diginatiivien, eli 1990-luvulla ja sen jälkeen syntyneiden, aiempia sukupolvia hauraampia persoonaltaan, pinnallisempia ja riippuvaisempia ulkoisista ärsykkeistä ja palautteesta. Omasta elämästä raportointi on tärkeämpää kuin elämä itse. Marginaali-ilmiöstä ei silti ole kyse, sillä esimerkiksi Isossa-Britanniassa nuoret käyttävät jo yli 30 tuntia viikossa medialaitteiden parissa. Greenfield väittääkin, että digimaailmassa kaikista tulee autistisia. Tämä tarkoittaa puutteellista kykyä tunnistaa ja ymmärtää toisten ihmisten tunteita. (Greenfield 2013.)

Aivotutkija Greenfieldin hyvä viesti on, että sisällöllä on merkitystä. Koulutuksen pitäisi hänen mukaan tarjota mahdollisimman monipuolista opetusta diginatiivien sukupolvelle: kirjallisuutta, historiaa ja ihmissuhdetaitoja. Sen lisäksi meidän tulisi kyseenalaistaa totuttuja kaavoja ja ajatusmalleja. Ilman luovuutta ei synny uusia aatteita, menestystuotteita tai -palveluja. Tässä on haastetta niin uudelle verkkomedialle kuin koulutusjärjestelmällekin.

Konstruktiivisen oppimisnäkemyksen mukaan kukaan ei ole "tyhjä taulu" (Rauste-von Wright 1994, 122). Median kuluttaja ei siis aloita asioiden seuraamista sosiaalisesta mediasta tai tiedotusvälineistä aina alusta. Journalistisen tuotteen kuluttaja on haaste journalismille. Vastassa voi olla mediakuluttaja, joka omaa paremmat tiedot aiheesta kuin toimitus tai toimittaja itse.

Journalistit ja toimitukset ovat yllättävän konservatiivisia. Vasta kriisiviestinnän tilanteet, joissa viranomaisten viestintä ei ole toiminut, ovat pakottaneet toimitukset luottamaan myös muunlaisiin lähteisiin tai kansalaisjournalismiin. Tsunamin aiheuttama luonnonkatastrofi Thaimaassa vuonna 2004 oli ensimmäinen suuri mediatapahtuma, jossa aktiiviset kansalaiset saivat tekstiviestien ja verkkosivustojen avulla selville onnettomuuden laajuuden, medioiden vasta odotellessa viranomaisten tiedotuksia asiasta (Huhtala, Hakala 2007, 75-77). Medioita voisi rohkaista etsimään erilaisia vaihtoehtoisia lähteitä myös normaalissa työssään. Toisaalta lehdet, radiot ja televisiot voisivat lisätä kansalaiskeskustelua ja pienentää poikkeavuuden aluetta, jossa poliittiseen valtavirtaan kuulumattomat ja hylätyt näkemykset jäävät kuulumatta (vrt. Vietnamin sodan uutisointi).

\section{MINKÄLAINEN ON KOULUTUKSEN IDENTITEETTI MEDIASSA JUURI NYT?}

Media ei myy yleisölleen vain tietoja vaan myös tunnetta, kokemuksia, samaistumista, yhteenkuuluvuutta, elämäntapaa ja erottumista. Vahvaa kokemusta erilaisuudesta ja paremmuudesta, jopa inhoa ja vihaa tarjoava media-aineisto on emotionaalisesti vaikuttavaa ja addiktoivaakin. Median kannalta on siis oman yleisösuhteensa vuoksi kannattavaa rakentaa voimakkaita samaistumisen ja erottautumisen mahdollisuuksia. (Luostarinen 2011.)

Onneksi emme kuitenkaan imeydy mediaesityksen maailmaan automaattisesti, vaan voimme tietoisesti rakentaa eroa kuvattuun todellisuuteen. Identifikaatio viittaakin yleisön tapaan sekä samaistua että tehdä eroa esitykseen, ja usein nämä prosessit vuorottelevat median käyttötilanteessa. Prosessit eivät kuitenkaan ole irrallisia mediankuluttajan muusta elämästä, sillä sosiaalinen tausta vaikuttaa identifikaatioiden muodostumiseen. Toisaalta media tuottaa kuvia, jotka väistämättä muotoilevat katsojien fantasioita ja identiteettejä myös heidän arkielämässään. (Herkman 2001, 187.) Media siis joko tarjoaa mediakuluttajalle identifioitumisen mahdollisuuden tai epää sen, joten sillä on valtava vastuu asiakkaidensa maailmankuvan rakentamisesta.

Koulutusmyllerrysten, säästöjen ja mediakeskustelun keskellä identiteetit joutuvat koetelluiksi. Koulutus on identifioitunut julkisuudessa mahdollisuudeksi, välttämättömyydeksi, tulevaisuuden toivoksi ja myös menoeräksi. Tämän hetken suomalaisessa viestintämaisemassa tiedotuskoneistoilla (valtioneuvosto, hallituspuolueet) ja valtamedian toimittajilla (Yle, Helsingin Sanomat, maakuntalehdet) on laaja konsensus suomalaisen talouden tasapainottamisen 
välttämättömyydestä ja lähialueidemme turvallisuuden heikkenemisestä. Näitä keskusteluaiheita vahvistetaan lukuisilla asiantuntijahaastatteluilla. Yleensä asiantuntijat ovat pankkien ekonomisteja tai armeijan kenraaleja.

Tällaisessa mediamaisemassa uutiset koulutuksen rahoitustarpeista merkitsevät uhkaa ja toiseutta. Siksi on virkistävää kuulla erilaisia, valtavirrasta poikkeavia ääniä. Vapaa kirjoittaja, tietokirjailija Elina Grundström toteaa, että kansalaisia kielletään arvostelemasta budjettileikkauksia, vaikka hallitusneuvotteluissa sovitut asehankinnat tulevat maksamaan 10 miljardia euroa. Eli sen saman, jonka tulevina vuosina säästämme koulutuksesta, lapsilta ja vanhuksilta. (HS 9.6.2015.) Vaihtoehtoinen ääni edustaa mediasivistystä parhaimmillaan. Tällaista keskustelua tarvitsemme yhteiskunnassa, jota kutsumme sivistysyhteiskunnaksi.

Tapio Kujala

YTT

Toiminnanjohtaja

Kansanvalistusseura

\section{LÄHTEET}

Anderson, B. (2007). Kuvitellut yhteisöt - nationalismin alkuperän ja leviämisen tarkastelua. Suom. Kuortti, J. Tampere: Vastapaino.

Anttonen, M. (2009). Etnisyys ja identiteetti. www.soc. utu.fi/opiskelu/opetusohjelma/Anttonen_Etnisyys_ ja_identiteetti_14.9.2009_1.luento_verkkoon.pdf

Bauman, Z. (1996). Postmodernin lumo. Toim. Ahponen, P. \& Cantell, T. Suom. J. Vainonen. Tampere: Vastapaino.

Greenfield, S. (2013). Haastattelu IT Future tapahtumassa 17.4.2013. www.fujitsu.com/fi/video (tarkistettu 2.9.2015)

Hall, S. (1999). Identiteetti. Suom. Lehtonen, M. \& Herkman, J. Tampere: Vastapaino.

Hallin, D. C. (1986). The "Uncensored War". The media and Vietnam. New York: Oxford Unversity Press.

Hallin, D. C. (2009). “Olohuonesota”. Teoksessa Wiest, A. (toim.) Vietnamin sota. Suom. S. Liikkanen. Jyväskylä: Ajatus-kirjat/Gummerus kustannus.

HS 9.6.2015. Suomessa tapahtuu asioita, jotka eivät ole normaaleja, vaikka niitä sellaisiksi väitetää [tämä edellinen lause kursiivilla]. Elina Grundströmin kolumni, Helsingin Sanomat.

Huhtala, H. \& Hakala, S. (2007). Kriisi ja viestintä. Helsinki: Gaudeamus.

Kujala, T. (2012). Lähi-idän mediasota. Journalismin ristipaineet Israelin ja palestiinalaisten välisessä konfliktissa. Tampere:Tampere University Press.

Linjakumpu, A. (2009). Islamin globaalit verkostot. Tampere: Vastapaino.

Meyrowitz, J. (1985). No sense of place. New York: Oxford University press.

Pietikäinen, S. \& Mäntynen, A. (2009). Kurssi kohti diskurssia. Tampere: Vastapaino.

Rauste-von Wright, M. \& von Wright, J. (1994). Oppiminen ja koulutus. Helsinki: Werner Söderström Osakeyhtiö.

Sen, A. (2009). Identiteetti ja väkivalta. Suom. J. Korhonen. Helsinki: Basam books. 